\title{
AGRONOMIC PERFORMANCE OF RADISH GENOTYPES UNDER DIFFERENT IRRIGATION DEPTHS
}

\author{
Fernando F. da Cunha ${ }^{*}$, Ivan P. de Souza ${ }^{2}$, Washington de O. Campos², \\ Valter C. de Andrade Júnior ${ }^{3}$, Thiago A. Magalhães ${ }^{3}$
}

${ }^{1 *}$ Corresponding author. Universidade Federal de Viçosa/ Viçosa - MG, Brasil.

E-mail: fernando.cunha@ufv.br | ORCID ID: 0000-0002-1671-1021

\section{KEYWORDS}

horticulture, irrigation management, Raphanus sativus.

\begin{abstract}
In radish production, the choice of proper genotypes and irrigation regime is of great importance to achieve success. In light of this, the current study aimed to evaluate the agronomic performance of a few radish genotypes under different irrigation strategies. The plants were grown in the city of Unaí - MG, in Brazil, under field conditions, and during two cycles, one of 40 days (from February 28 to April 8, 2015) and other of 51 days (from May 9 to June 28, 2015). The experimental design was a randomized block design in a split-plot arrangement with four replications. The treatments consisted of four irrigation strategies $(50,75,100$, and $125 \%$ of crop evapotranspiration - ETc) applied by a dripping irrigation system, while subplots consisted of three radish cultivars (Comet, Saxa, and Crimson Giant). We evaluated the following parameters: root system depth, leaf chlorophyll content, shoot fresh matter, diameter and length of tuberous root, number, and mass of commercial and non-commercial tuberous roots, and water use efficiency. All the radish genotypes showed no differences for agronomic characteristics. Under Brazilian Cerrado conditions, the most suitable irrigation strategy for radish crops is $100 \%$ of ETc.
\end{abstract}

\section{INTRODUCTION}

The last survey carried out by Embrapa (2017) indicates that Brazil has 800 thousand hectares destined for vegetable crops, with a production of 19.3 million tons and productivity of 24.1 tons per hectare. This vegetable production is usually concentrated next to the great consumer centers, also called green belts. The production is distinguished by high seasonality and perishability, in which consumption goes through variations throughout the year, hindering the distribution of these agricultural products.

A large consumer of vegetable crops in Brazil is the Brasília city, the federal capital also known as the capital of the Cerrado, which has a population of approximate 2.8 million people. A survey carried out by Silva \& Costa (2013) showed that $82 \%$ of the population of Brasília consume vegetables more than five times a week and $24 \%$ of them feed more than three servings per day.

To meet this consumption, there is a need for production near this center. A possibility is the production of vegetable crops in the northwest of the State of Minas
Gerais, near the city of Brasília. This region is also belonging to the Cerrado biome and stands out in grain production and dairy farming, presenting low development in to plant of vegetable crops. However, due to this possibility of the consumer market in the Federal District and the increased number of family farmers in this region (Sousa et al., 2011), there are good possibilities in the production of vegetable crops, such as radish.

Radish (Raphanus sativus L.) belongs to the Brassicaceae family, whose roots are globular of bright scarlet color and white edible pulp. Radish is consumed raw and presents a high food value, and is considered a good source of calcium, iron, and phosphorus (Slomp et al., 2011; Carmichael et al., 2012). This vegetable does not tolerate transplantation and sowing must occur in definitive beds (Lacerda et al., 2017). Radish crop develops well in fertile soils and harvesting takes place 3 to 6 weeks after sowing, depending on the season (Lima et al., 2015). According to Bregonci et al. (2008), despite being a crop of little importance in terms of planted area, it has good financial viability.

\footnotetext{
${ }^{2}$ Universidade Federal dos Vales do Jequitinhonha e Mucuri/ Unaí - MG, Brasil.

${ }^{3}$ Universidade Federal de Lavras/ Lavras - MG, Brasil.

Received in: 1-31-2018

Accepted in: 2-5-2019
} 
The Northwest of Minas Gerais presents annual averages of temperature and precipitation of $25{ }^{\circ} \mathrm{C}$ and 1,200 mm, respectively (Cunha et al., 2018). Its topography is gently undulating and the regional climate is Aw according to the Köppen classification, with a dry winter and precipitations concentrated in the summer. These characteristics make radish production a viable alternative in this region, especially for small farmers.

Existing scientific studies on the agronomic behavior of the radish crop under Brazilian Cerrado conditions, specifically in the northwestern region of Minas Gerais, are still insufficient and their cultivation is still based on empirical practices carried out by farmers, lacking references of scientific research results. Therefore, there is a need to study the adaptation of radish genotypes to the edaphoclimatic conditions of the region, using maximizing in productivity. Many producers, ignoring this fact, continue to use the same cultivars that their ancestors used, making the radish crop less productive and discouraging this cultivation (Cunha et al., 2017).

In addition to selecting the material appropriate to the soil and climate, the success in radish cultivation requires on the use of irrigation to supply fully or supplement the water requirements of the crop. Water deficiency is usually the most limiting factor for obtaining high productivity and good quality products (Carmichael et al., 2012; Abdel, 2015; Cunha et al., 2017), but its excess can also be detrimental. Soil water content during the crop cycle should be maintained constant, avoiding fluctuations to avoid cracks in the roots and decreases in quality (Silva et al., 2012; Alves et al., 2017; Silva et al., 2017; Noman et al., 2018).
Therefore, the aim of this study was to identify the optimal irrigation strategies and determine the best radish genotypes for the climate and soil conditions of the Brazilian Cerrado.

\section{MATERIAL AND METHODS}

Radish was grown under field conditions during two cycles with duration of 40 (February 28 to April 8, 2015) and 51 days (May 9 to June 28, 2015). The experiments were carried out in the experimental area of the Juvêncio Martins Ferreira State School, in the municipality of Unaí, MG. The geographical coordinates of the site are $16^{\circ} 22^{\prime} 45^{\prime \prime}$ $\mathrm{S}$ and $46^{\circ} 53^{\prime} 45^{\prime \prime} \mathrm{W}$, with $460 \mathrm{~m}$ of altitude. The climate is classified as Aw, with an annual air temperature between 10 to $35{ }^{\circ} \mathrm{C}$ and average precipitation of $1,200 \mathrm{~mm}$ concentrated in the summer and dry winter.

The soil of the experimental is classified as a clayey textured Oxisol (Latossolo Vermelho-Amarelo, Brazilian Soil Classification System) with good drainage. The soil had a bulk density of $1.09 \mathrm{~g} \mathrm{~cm}^{-3}$ and water contents equivalent to permanent wilting point and field capacity, with values of 0.182 and $0.315 \mathrm{~cm}^{3} \mathrm{~cm}^{-3}$, respectively.

Soil tillage was performed with a rotary hoe throughout the experimental area and then beds were manually built using hoes. These beds had a width of $1 \mathrm{~m}$ and a height of $25 \mathrm{~cm}$. Soil chemical features were obtained before each cultivation cycle and carried out at the Laboratory of Chemical Soil Analysis of the Agricultural and Environmental Technology Center of Paracatu, MG (Table 1). Fertilization was not recommended because nutrient contents were suitable for the radish cultivation cycles (Vidigal \& Pedrosa, 2007).

TABLE 1. Results of soil chemical analysis at the beginning of the experiments. Unaí, MG, 2015.

\begin{tabular}{|c|c|c|c|c|c|c|c|c|c|c|}
\hline \multirow{2}{*}{ Cycle } & \multirow{2}{*}{$\begin{array}{c}\mathrm{pH} \\
\cdots \mathrm{H}_{2} \mathrm{O} \cdots \\
\end{array}$} & $\mathrm{P}$ & $\mathrm{K}$ & $\mathrm{Ca}^{2+}$ & $\mathrm{Mg}^{2+}$ & $\mathrm{Al}^{3+}$ & $\mathrm{H}+\mathrm{Al}$ & $\mathrm{CEC}$ & V & $\mathrm{OM}$ \\
\hline & & \multicolumn{2}{|c|}{$\cdots \cdots \cdots \mathrm{mg} \mathrm{dm}^{-3 \ldots \ldots \ldots}$} & \multicolumn{5}{|c|}{ 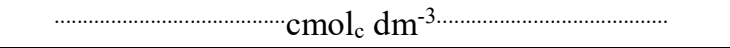 } & \multicolumn{2}{|c|}{$\ldots \ldots \ldots \ldots \ldots \ldots \ldots \ldots \ldots \ldots$} \\
\hline 1 & 5.4 & 57.5 & 95.4 & 5.2 & 1.8 & 0.1 & 2.5 & 9.7 & 74.7 & 1.1 \\
\hline 2 & 5.2 & 35.0 & 64.2 & 5.3 & 1.9 & 0.1 & 1.9 & 9.3 & 79.1 & 1.7 \\
\hline
\end{tabular}

Available $\mathrm{K}$ and $\mathrm{P}$ extracted with Mehlich I; $\mathrm{Al}, \mathrm{Mg}$, and Ca extracted with $1 \mathrm{~mol} \mathrm{~L}^{-1} \mathrm{KCl}$.

The experiments were installed in a randomized block design in a split-plot arrangement, with plots consisting of four irrigation depths, subplots consisting of three radish genotypes, and four replications. Sample units (replications) had dimensions of $0.8 \mathrm{~m}$ width and $1.0 \mathrm{~m}$ length, as in Castro et al. (2016), with a total area of $0.8 \mathrm{~m}^{2}$. These sample units were composed of four rows of cultivation, each row with 10 plants, totaling 40 radish plants.

The treatments consisted of four irrigation strategies to replace $50,75,100$, and $125 \%$ of crop evapotranspiration (ETc), and the radish genotypes Comet (Isla Company), Saxa (Isla Company), and Crimson Giant (Top Seed Company). A dripping irrigation system with tapes (Petroisa Company) of $0.016 \mathrm{~m}$ in diameter was used. The spacing between drip tapes was $0.4 \mathrm{~m}$, irrigating two rows of radish crop per lateral line. The emitters (drippers) irrigated with an operating pressure of $98 \mathrm{kPa}(\sim 10 \mathrm{mca})$, providing an approximate flow of $1.8 \mathrm{~L} \mathrm{~h}^{-1}$, being spaced $0.2 \mathrm{~m}$ from each other. Line-in connectors with valves were used to differentiate the treatments with irrigation depths. According to the time required to apply the different irrigation depths, the valves were opened or closed to obtain the different water depths in the treatments.

Direct sowing was performed with spacing of 0.05 $\mathrm{m}$ between radish crop and $0.2 \mathrm{~m}$ between planting rows. The thinning occurred 12 days after sowing (when $50 \%$ of the radish plants had five definitive leaves), obeying a spacing of $0.1 \mathrm{~m}$ between plants.

Irrigation frequency (IF) was fixed for each crop stage, with the IF for the first stage of one day and for the later stages of two days. The net irrigation depth needed for the treatment with $100 \%$ ETc water replenishment was defined according to parameters of climate, soil, plant and irrigation system (Equation 1), representing the crop water requirement. 


$$
\mathrm{NID}=\sum_{\text {day } 1}^{i} \text { ETo } K_{C} K_{S} K_{L}-\mathrm{P}_{E}
$$

Where,

NID is the net irrigation depth (mm);

ETo is the reference evapotranspiration $\left(\mathrm{mm} \mathrm{day}^{-1}\right)$;

$\mathrm{K}_{\mathrm{C}}$ is the crop coefficient (dimensionless);

$\mathrm{K}_{\mathrm{S}}$ is the soil moisture coefficient (dimensionless);

$\mathrm{K}_{\mathrm{L}}$ is the location coefficient (dimensionless), and

$\mathrm{P}_{\mathrm{E}}$ is the effective precipitation in the period $(\mathrm{mm})$.
The Penman-Monteith-FAO56 methodology (Allen et al., 1998) was used to calculate reference evapotranspiration (ETo). The daily agrometeorological data to estimate ETo were taken from INMET (Brazilian National Institute of Meteorology), from Unaí, MG station. The behavior of daily meteorological in the two cycles of radish cultivation are shown in Figure 1. Precipitation was measure by means of a pluviometer installed in the experimental area. The effective precipitation was that used directly by the radish crop (Bernardo et al., 2006), i.e. the water necessary to raise the current moisture at the instant of precipitation to the moisture equivalent to field capacity.
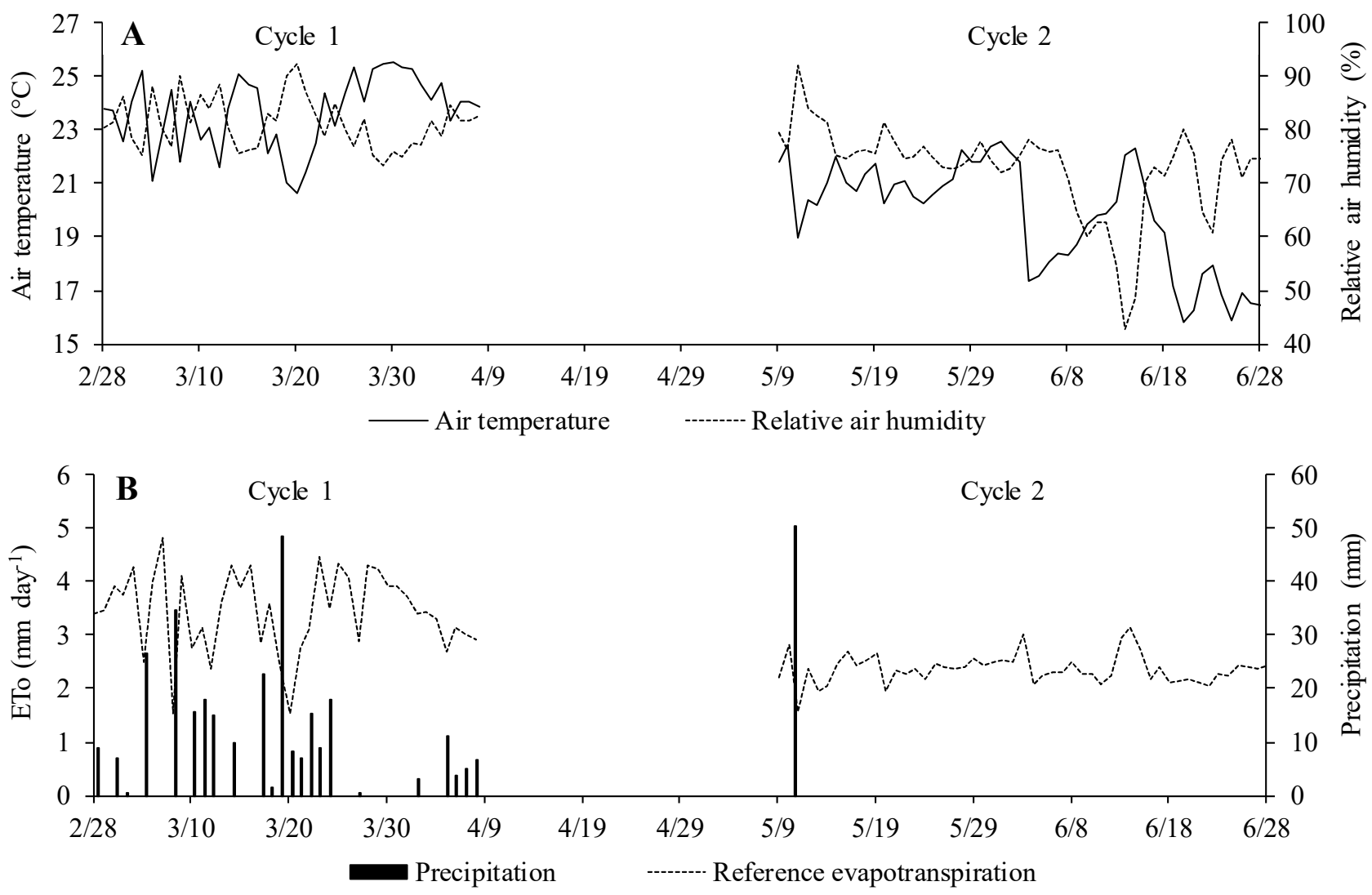

FIGURE 1. Variation of (A) relative air humidity (\%), air temperature $\left({ }^{\circ} \mathrm{C}\right)$, (B) precipitation $(\mathrm{mm})$ and reference evapotranspiration $\left(\mathrm{mm} \mathrm{day}^{-1}\right)$ for the two cycles of radish cultivation. Unaí, MG, UFVJM, 2015.

The applied crop coefficients $\left(\mathrm{K}_{\mathrm{C}}\right)$ were 0.7 and 1.0 for growth stages I and III, respectively. For stage II, a linear weighting was used from the end of stage I and the beginning of stage III. The duration of stages I and II were 10 days each, while stage III lasted from the 20th day to the harvest. Soil moisture $\left(\mathrm{K}_{\mathrm{S}}\right)$ and location coefficients $\left(\mathrm{K}_{\mathrm{L}}\right)$ were calculated according to eqs (2) and (3), respectively.

$$
\begin{aligned}
& K_{S}=\frac{\operatorname{Ln}(\mathrm{CWD}+1)}{\operatorname{Ln}(\mathrm{TWC}+1)} \\
& K_{L}=\frac{P}{100}+0.15\left(1-\frac{P}{100}\right)
\end{aligned}
$$

Where,

$\mathrm{K}_{\mathrm{S}}$ is the soil moisture coefficient (dimensionless);

LAA is the current soil water depth (mm);

TWC is the total soil water capacity (mm);
$\mathrm{K}_{\mathrm{L}}$ is the location coefficient (dimensionless), and

$P$ is the highest value between the percentages of wet or shaded area (\%).

The values of net water depth were corrected according to the irrigation efficiency in the system, defining the gross water depth according to eq. (4). Irrigation efficiencies in cycles 1 and 2 were 92.9 and $90.3 \%$, respectively.

$$
\mathrm{GID}=\frac{\mathrm{NID}}{\mathrm{Ei}}
$$

Where,

GID is the gross irrigation depth (mm);

NID is the net irrigation depth ( $\mathrm{mm}$ ), and

Ei is the irrigation efficiency (decimal). 
The variables used for the evaluation of treatments in the radish crop were:

1. Root depth $(\mathrm{cm})$ : obtained by means of opening a trench lateral to the plants using a mattock. After removal of the entire root system, the soil adhered to the roots was retired and the plant was taken to measure the distance between the collar and root end using a $0.001 \mathrm{~m}$ scale ruler. These measures were performed in six plants previously identified at the beginning of the crop cycles, as in Cunha et al. (2018). 2. Leaf chlorophyll content (SPAD): obtained by using a portable electronic meter (chlorophyll meter) model SPAD 502, manufactured by Konica Minolta Sensing, Inc. (Konica Minolta, 2009). At each plot, 18 measurements were performed, with three measurements per plant in fully developed and healthy leaves.

3. Shoot fresh matter $\left(\right.$ g plant $\left.^{-1}\right)$ : obtained by removing the shoot of six plants and measuring their respective weights.

4. Tuberous root diameter $(\mathrm{cm})$ : obtained by the mean of two measures perpendicular to the length of six tuberous roots, i.e. the transversal measurement of the root. A caliper was used for this measurement.

5. Tuberous root length $(\mathrm{cm})$ : measured between the leaf insertion and the beginning of the root, i.e. the longitudinal measurement of the root. A $0.1 \mathrm{~cm}$ scale ruler was used and the measurement was performed on six tuberous roots.

6. Non-commercial tuberous roots (unit $\mathrm{m}^{-2}$ ): any tuberous root with cracks, surface defects, irregular shapes or other defects that could prevent its commercialization were considered as non-commercial.

7. Commercial tuberous roots (unit $\mathrm{m}^{-2}$ ): any tuberous root that presented the favorable criteria to commercialization.

8. Mass of non-commercial tuberous roots $\left(\mathrm{kg} \mathrm{m}^{-2}\right)$ : the fresh mass referring to tuberous roots classified as noncommercial.

9. Mass of commercial tuberous roots $\left(\mathrm{kg} \mathrm{m}^{-2}\right)$ : obtained by means of the fresh mass referring to tuberous roots classified as commercial.

10. Water use efficiency $\left(\mathrm{kg} \mathrm{m}^{-3}\right)$ : obtained by the ratio between the total fresh tuberous root mass of radish at the plot and the volume of water applied.

The data were submitted to the analyses of variance and regression. The mean comparison was performed using the Tukey's test at 5\% probability. For quantitative factors, linear and quadratic models were tested. Model selection was based on the significance of regression coefficients using the t-test at $5 \%$ probability, coefficient of determination $\left(\mathrm{R}^{2}\right)$, and biological phenomenon. For the execution of statistical analyses, the experimental package Designs of the software R was used.

\section{RESULTS AND DISCUSSION}

The radish crop presented the same water demand in both crop cycles (Table 2). Although cycle 1 presented higher evapotranspiration rates (Figure 1B), cycle 2 lasted eleven days more. Table 2 also shows that the radish crop presented a lower demand for irrigation in cycle 1 due to higher effective precipitation heights. Effective precipitation, according to Bernardo et al. (2006), is the rainfall fraction used directly by the crop, i.e. the amount of water that the radish crop used in its physiological processes. The difference between the effective precipitation and rainfall was the amount of water that runoff and percolated below the crop root system after the soil immediately above reached the moisture equivalent to field capacity. In the treatment of irrigation depth of $50 \%$ ETc of cycle 1, for example, from the $296 \mathrm{~mm}$ of water added to the soil via precipitation, only $46.5 \mathrm{~mm}$ was considered effective, i.e. it was available in the soil for the crop. This small use was due to the high irrigation interval and precipitations that occurred in periods when radish crop had lower values of crop coefficient. Thus, the soil always had the moisture close to the field capacity, requiring little water to reach the available water capacity.

TABLE 2. Effective precipitation, net water depth, and total water depth received by each treatment and cycle of radish cultivation. Unaí, MG, UFVJM, 2015.

\begin{tabular}{clcccc}
\hline \multirow{2}{*}{ Cycle } & \multicolumn{1}{c}{ Event } & \multicolumn{4}{c}{ Irrigation depths } \\
\cline { 3 - 6 } & & $50 \%$ ETc & $75 \%$ ETc & $100 \%$ ETc & $125 \%$ ETc \\
\hline \multirow{2}{*}{1} & Effective precipitation $(\mathrm{mm})$ & 46.5 & 44.3 & 42.3 & 42.3 \\
& Net water depth (mm) & 33.6 & 50.3 & 67.1 & 83.9 \\
& Total water depth (mm) & 80.0 & 94.6 & 109.4 & 126.2 \\
\hline \multirow{2}{*}{2} & Effective precipitation $(\mathrm{mm})$ & 5.2 & 4.8 & 4.5 & 4.5 \\
& Net water depth (mm) & 52.3 & 78.5 & 104.6 & 130.8 \\
& Total water depth (mm) & 57.5 & 83.3 & 109.1 & 135.3 \\
\hline
\end{tabular}

Isolated effects of genotypes and irrigation depths were observed for root depth in cycle 2 of the radish crop (Table 3). Comet and Crimson Giant presented higher root depths in relation to the genotype Saxa. In addition, irrigation depths in cycle 2 provided a reduction of root depth of the radish crop (Figure 2). Possibly, in treatments with lower irrigation depths, the crop deepened its root system to extract water in lower soil layers. This did not occur in cycle 1 because of the higher precipitation that occurred in this crop cycle (Figure 1). 
TABLE 3. Average values of root depth (RD, in $\mathrm{cm}$ ), leaf chlorophyll content (LCC, in SPAD), shoot fresh matter (SFM, in $\mathrm{g}$ plant $\left.^{-1}\right)$, tuberous root diameter ( $\mathrm{RDi}$, in $\left.\mathrm{cm}\right)$ and length $(\mathrm{RL}$, in $\mathrm{cm})$, commercial and non-commercial tuberous roots $(\mathrm{CR}$ and $\mathrm{NCR}$, in unit $\mathrm{m}^{-2}$ ), mass of commercial and non-commercial tuberous roots (MCR and MNCR, in $\mathrm{kg} \mathrm{m}^{-2}$ ), and water use efficiency (WUE, in $\mathrm{kg} \mathrm{m}^{-3}$ ) as a function of different radish genotypes (RG) and irrigation depths (ID) in two cultivation cycles. Unaí, MG, UFVJM, 2015.

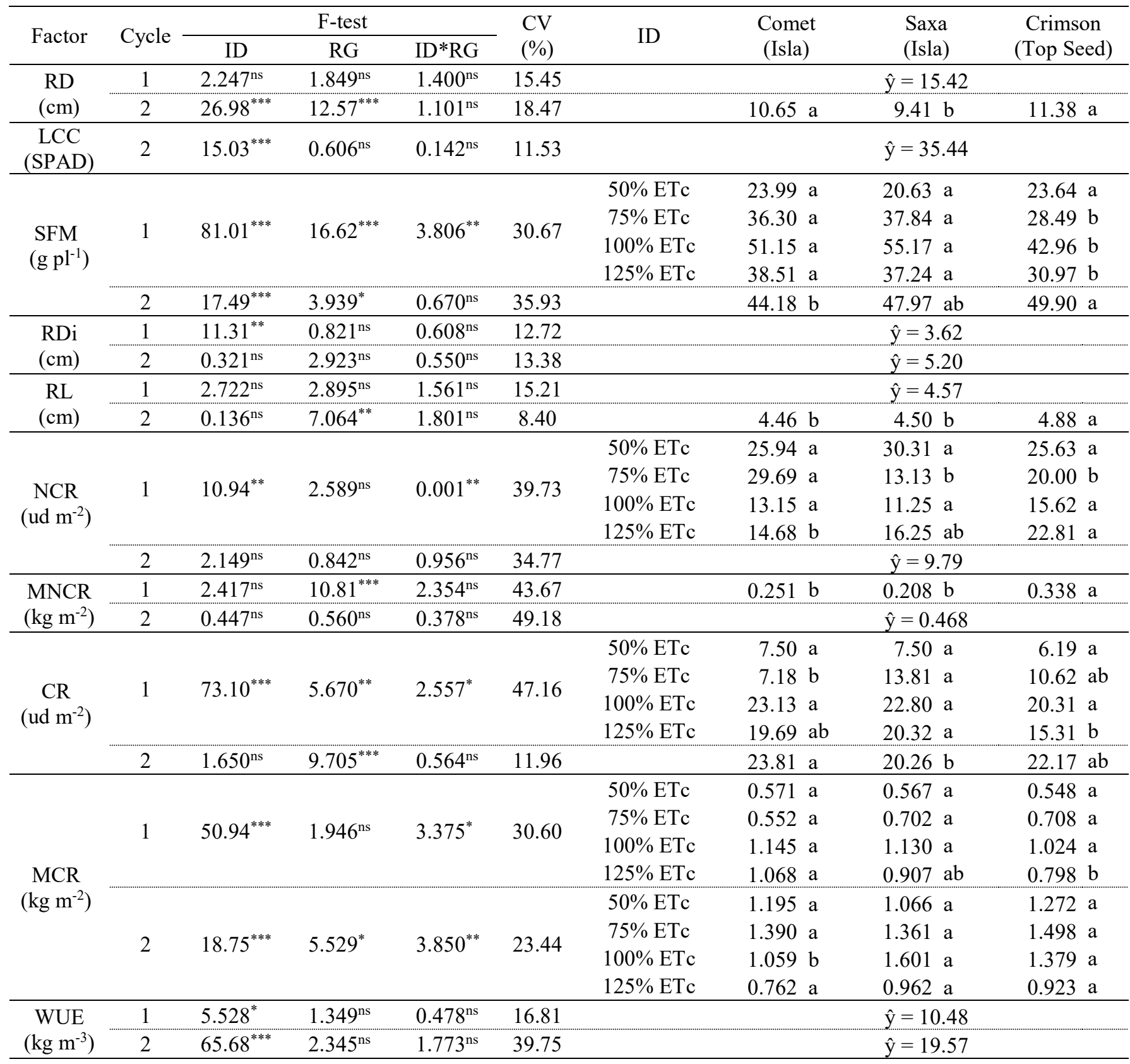

$* p<0.05 ; * * p<0.01 ; * * * p<0.001 ;{ }^{\text {ns }}$ non-significant. Means followed by the same letter in the row did not differ from each other by the Tukey's test $(p<0.05)$. 

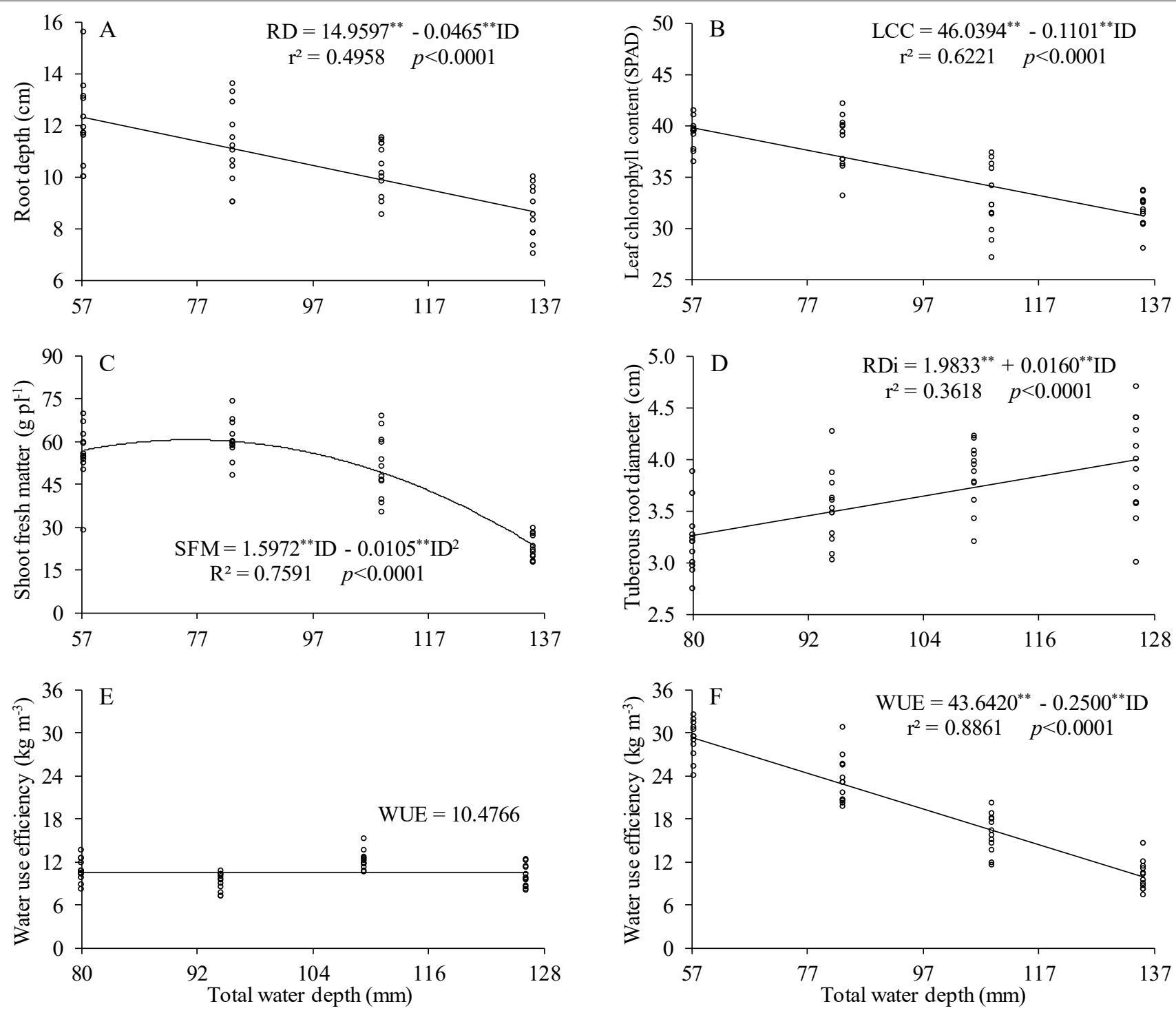

** and * significant at 1 and $5 \%$ probability, respectively.

FIGURE 2. Estimation of root depth (A), leaf chlorophyll content (B), shoot fresh matter (C), and water use efficiency (E) in cycle 2 of radish and tuberous root diameter (D) and water use efficiency (F) in cycle 1 as a function of total water depths (ID). Unaí, MG, UFVJM, 2015.

No effect of genotypes was observed on leaf chlorophyll content of the radish crop (Table 3). This behavior was not observed by Ayyub et al. (2016), who tested six radish cultivars and found differences in this parameter. The increase in chlorophyll content provides greater development of chloroplasts and consequent addition in leaf nitrogen content (Piekielek \& Fox, 1992; Smeal \& Zhang, 1994). However, an isolated effect of irrigation depths was observed on leaf chlorophyll content of the radish crop (Table 3). Figure 3 shows that irrigation depths provided a reduction in leaf chlorophyll content of the radish. According to the results found in this study, water availability is essential in this process. However, Abdalhi et al. (2016) reported that water stress due to lack or excess of irrigation is not a criterion for reaching a high leaf chlorophyll content. This was also observed by Lacerda et al. (2017), who applied irrigation depths of 50, 75, 100, and $125 \%$ of ETo and did not verify the difference in leaf chlorophyll content of the radish Crimson Giant.

An interaction was observed in cycle 1 and the isolated effects of genotypes and irrigation depths were observed in cycle 2 for shoot fresh matter of radish (Table
$3)$. In cycle 1, the irrigation depth of 50\% ETc showed no difference, while in the water depths of 75,100 , and $125 \%$ ETc, the Crimson Giant presented lower values in relation to the other radish genotypes (Table 3). The genotypes Comet and Saxa did not differ in any cycle, which is in accordance with the results of Cunha et al. (2017), who applied the same treatments in Chapadão do Sul, MS.

Irrigation depths provided a quadratic effect on the radish shoot matter in both cycles of cultivation. In cycle 1 , according to the regression equations, total water depths of 109.9 (100\% ETc), 108.7 (99\% ETc) and $109.2 \mathrm{~mm}(99 \%$ ETc) maximized the shoot fresh matter of the cultivars Comet, Saxa, and Crimson Giant, with values of 47.1, 50.5, and 37.9 g plant $^{-1}$, respectively (Figure 3 ). In cycle 2, the total water depth of $75.9 \mathrm{~mm}(69 \%$ ETc) maximized the shoot fresh matter of the radish, resulting in a value of 60.6 g plant $^{-1}$ (Figure 2). Carmichael et al. (2012) studied the radish crop in Swaziland and verified increases in shoot production in treatments with higher water replenishments in the soil. Cunha et al. (2017) also observed a quadratic effect in the rainy season, and the irrigation depth that maximized radish shoot matter was $96 \%$ ETc. 

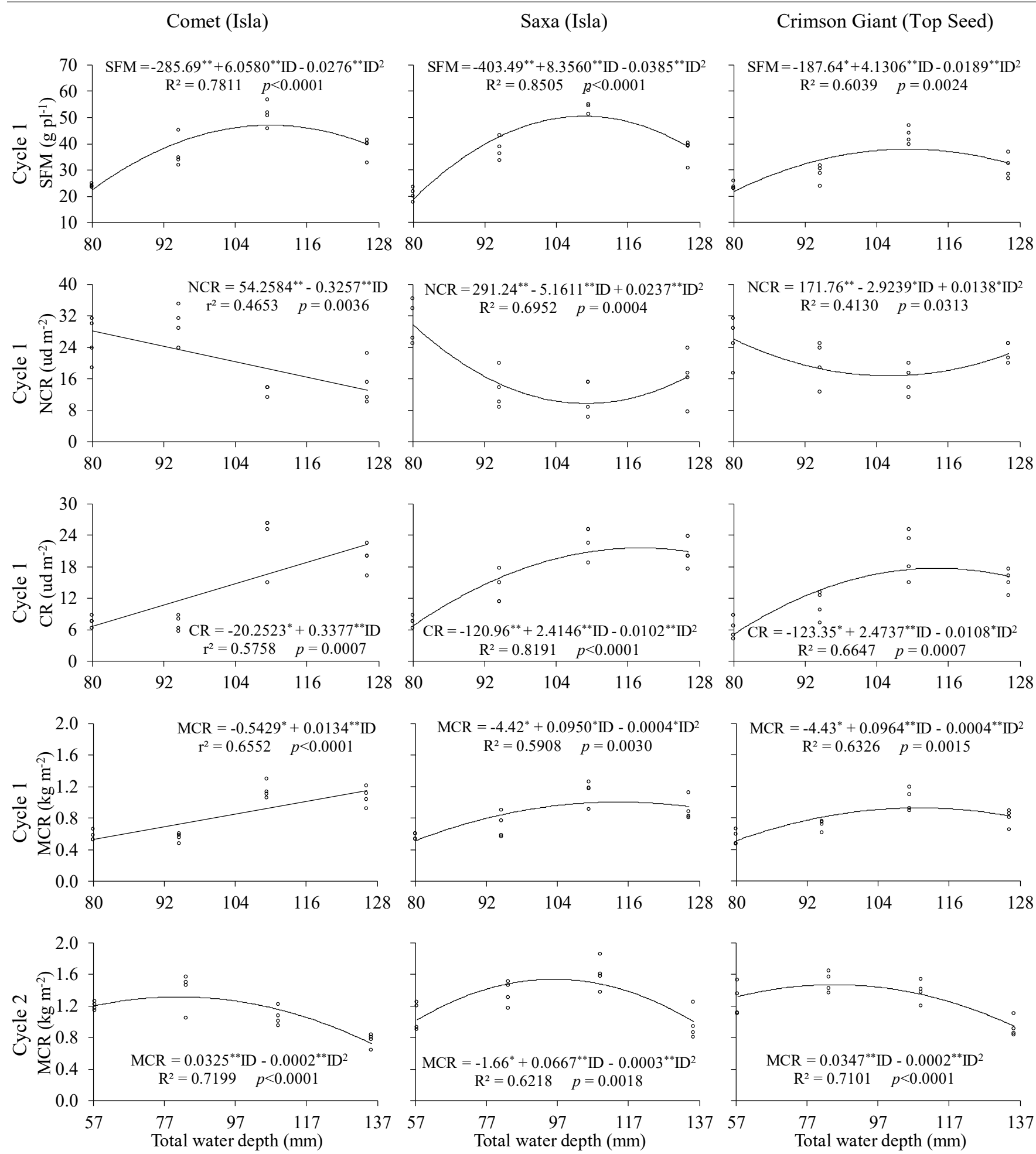

** and * significant at 1 and 5\% probability, respectively.

FIGURE 3. Shoot fresh matter (SFM), non-commercial (NCR) and commercial tuberous roots (CR) for cycle 1 of radish and mass of commercial tuberous roots (MCR) for cycles 1 and 2 as a function of total water depths (ID) for different radish genotypes. Unaí, MG, UFVJM, 2015.

Tuberous root diameter was not influenced by genotype in any evaluated cycle (Table 3). Faria et al. (2013) also observed no difference between the genotypes Comet and Saxa in Nova Xavantina, MT. Root diameter values found by these authors were similar to those obtained in our study. Only total water depths affected the radish root diameter in cycle 1 (Table 3), with an increasing linear effect (Figure 2), which is in accordance with Abdel (2015) and Lacerda et al. (2017). Root diameter values increased from 32.6 to $40.0 \mathrm{~mm}$ from the total water depth of 80.0 to $126.2 \mathrm{~mm}$, generating an increase of $22.7 \%$, according to the regression equation. Lacerda et al. (2017) obtained increases of $21.2 \%$ using the same irrigation depths. This increase is interesting in order to obtain radish with a better pattern, being more valued in the market. 
In Cycle 2, the cultivar Crimson Giant presented a longer tuberous root length in relation to the other genotypes, which did not differ from each other (Figure 3). Regardless of the cycle, irrigation depths did not have an effect on root length (Figure 3), which is in accordance with Lima et al. (2015), who applied different soil water stresses in radish cultivation in Lavras, MG.

An interaction was observed between genotypes and irrigation depths for the number of non-commercial tuberous roots of radish in cycle 1 (Table 3 ). No differences were observed between the evaluated genotypes in the irrigation depth of $100 \%$ ETc of cycle 1 and in all irrigation depths of cycle 2 (Table 3 ). Figure 3 shows a negative linear effect of total water depths on the number of noncommercial tuberous roots of the genotype Comet grown in cycle 1 . The other genotypes had a quadratic effect and according to the regression equations, total water depths of 109.1 (99\% ETc) and $106.0 \mathrm{~mm}(94 \% \mathrm{ETc})$ reduced the number of non-commercial roots of the cultivars Saxa and Crimson Giant, with values of 9.8 and 16.8 units $\mathrm{m}^{-2}$, respectively (Figure 3). This indicates that both water deficit and excess affected radish quality, which is in accordance with Alves et al. (2017) and Noman et al. (2018). Silva et al. (2017) reported that the presence of cracks is one of the reasons of making a radish noncommercial, but the best way to prevent cracking in roots is to maintain a uniform water supply. Silva et al. (2012) tested radish tolerance to soil wetting in Mossoró, $\mathrm{RN}$, and observed its sensitivity to water saturation, especially when stress occurred in the first development stages of the plants, concluding that the radish root system is more sensitive to wetting than the shoot.

The mass of non-commercial tuberous root of radish had an isolated effect of genotypes in cycle 1, with Crimson Giant presenting higher losses in relation to the other genotypes, which did not differ from each other (Table 3). The same behavior was expected for the number of noncommercial tuberous roots, but it did not occur since the mass of non-commercial tubers possibly presented a heterogeneous pattern, increasing the coefficient of variation and not allowing a statistical differentiation.

The genotypes conferred effect on the number of commercial tuberous roots of radish in both evaluated cycles (Table 3 ). An interaction was observed in cycle 1 and regardless of the irrigation depth, the genotype Saxa always showed a higher number of commercial roots, not differing from Crimson Giant in cycle 2, but with a lower value in relation to Comet. Cunha et al. (2017) found no difference between the number of commercial roots between the cultivars Saxa and Comet in any evaluated cycle.

Total water depths provided a positive linear effect on the number of commercial tuberous roots of the cultivar Comet in cycle 1 (Figure 3 ). In the other genotypes, the effect was quadratic and according to the regression equations, total water depths of 118.1 (113\% ETc) and $114.0 \mathrm{~mm}(106 \% \mathrm{ETc})$ increased the number of commercial roots of the radishes Saxa and Crimson Giant, with values of 21.6 and 17.7 units $\mathrm{m}^{-2}$, respectively (Figure 3 ).

An interaction was observed between genotypes and irrigation depths for the mass of commercial roots of radish in both evaluated cycles (Table 3). However, as observed for most of the agronomic characteristics evaluated in this study, the superiority of one genotype was not verified over the other. Thus, it is not possible to indicate a single radish material to be cultivated in the Brazilian Cerrado. In addition, other studies should be carried out with these materials and others in the market for a better recommendation.

Except for the genotype Comet in cycle 1, irrigation depths provided a quadratic effect on the mass of commercial tuberous root of radish (Figure 3), in which the total water depth close the optimal point was $109.4 \mathrm{~mm}$ (100\% ETc). Klar et al. (2015) applied irrigation depths to supply 25, 50, 75, 100, and 125\% ETc in Botucatu, SP, and also observed this behavior in both evaluated cycles, but the irrigation depth of $80 \%$ ETc maximized this parameter.

Considering that for most of the evaluated agronomic characteristics water depths close to $100 \%$ ETc maximized beneficial parameters and minimized those harmful, its use is recommended to supply the requirements for radish irrigation in the Brazilian Cerrado. Thus, it is expected to save water and electricity in radish production in order to increase its economic viability.

The water use efficiency (WUE) in cycles 1 and 2 were, on average, 10.5 and $19.5 \mathrm{~kg} \mathrm{~m}^{-3}$, respectively. This result indicates that to produce $1.0 \mathrm{~kg}$ of fresh radish mass, 95.5 and 51.2 liters of irrigation depth was required in crop cycles 1 and 2, respectively. An isolated effect of irrigation depths was observed in WUE for radish in both crop cycles (Table 3 ). It was not possible to adjust a regression equation in cycle 1 and in cycle 2 the irrigation depths provided a negative linear effect on WUE by radishes (Figure 2). This result was already expected since they are inversely proportional factors. Slomp et al. (2011) cultivated radish in Erechim, RS, and also verified a linear reduction of WUE when applying irrigation depths to meet the demand of 40 to $120 \%$ of the evaporation of the class A tank.

\section{CONCLUSIONS}

The radishes Comet, Saxa, and Crimson Giant showed no differences in their agronomic characteristics when cultivated in the Brazilian Cerrado.

The recommended irrigation strategy for radish crop in the Brazilian Cerrado and regions with similar conditions is the replacement of $100 \%$ of the crop evapotranspiration.

\section{ACKNOWLEDGMENTS}

This research was supported by the Coordination for the Improvement of Higher Education Personnel of Brazil (CAPES), with the Financing Code 001, and by the Minas Gerais Research Foundation (FAPEMIG). The authors also thank the Agricultural School of Unaí, MG, and Prof. Elvis Melo for the facilities.

\section{REFERENCES}

Abdalhi MAM, Cheng J, Feng S, Yi G (2016) Performance of drip irrigation and nitrogen fertilizer in irrigation water saving and nitrogen use efficiency for waxy maize (Zea mays L.) and cucumber (Cucumis sativus L.) under solar greenhouse. Grassland Science 62(3):174187. DOI: http://dx.doi.org/10.1111/grs.12125 
Abdel CG (2015) Fibrous root dimensions of four radish (Raphanus sativus L. var. sativus) cultivars grown in controlled cabinets under varying temperatures and irrigation levels. International Journal of Farming and Allied Sciences 4(3):253-266.

Allen RG, Pereira LS, Raes D, Smith M (eds) (1998) Crop evapotranspiration: guidelines for computing crop water requirements. FAO, 297p.

Alves ES, Lima DF, Barreto JAS, Santos DP, Santos MAL (2017) Determinação do coeficiente de cultivo para a cultura do rabanete através de lisimetria de drenagem. Irriga 22(1):194-203. DOI:

http://dx.doi.org/10.15809/irriga.2017v22n1p194-203

Ayyub CM, Shaheen MR, Raza S, Yaqoob MS, Qadri RWK, Azam M, Ghani MA, Khan I, Akhtar N (2016) Evaluation of different radish (Raphanus sativus) genotypes under different saline regimes. American Journal of Plant Sciences 7(6):894-898. DOI: http://dx.doi.org/10.4236/ajps.2016.76084

Bernardo S, Soares AA, Mantovani EC (2006) Manual de irrigação. Viçosa, Editora UFV, 625p.

Bregonci IS, Almeida GD, Brum VJ, Zini Júnior A, Reis EF (2008) Desenvolvimento do sistema radicular do rabanete em condição de estresse hídrico. Idesia 26(1):3338. DOI: http://dx.doi.org/10.4067/S071834292008000100005

Carmichael PC, Shongwe VD, Masarirambi MT, Manyatsi AM (2012) Effect of mulch and irrigation on growth, yield and quality of radish (Raphanus sativus L.) in a semi-arid sub-tropical environment. Asian Journal of Agricultural Sciences 4(3):183-187.

Castro BF, Santos LG, Brito CFB, Fonseca VA, Bebé FV (2016) Produção de rabanete em função da adubação potássica e com diferentes fontes de nitrogênio. Revista de Ciências Agrárias 39(1):455-472. DOI:

http://dx.doi.org/10.19084/RCA15131

Cunha FF, Castro MA, Godoy AR, Magalhães FF, Leal AJF (2017) Irrigação de cultivares de rabanete em diferentes épocas de cultivo no nordeste sul-matogrossense. Irriga 22(3):530-546. DOI:

http://dx.doi.org/10.15809/irriga.2017v22n3p530-546

Cunha FF, Souza IP, Campos WO, Andrade Júnior VC, Magalhães TA, Aleman CA (2018) Performance of arugula genotypes under irrigation depths on Brazilian Cerrado. Ciência e Agrotecnologia 42(3):271-280. DOI: http://dx.doi.org/10.1590/1413-70542018423029517

EMBRAPA - Embrapa Hortaliças (2017) Ciência e tecnologia são responsáveis pelo aumento da produção de hortaliças. Available:

http://www.cpafap.embrapa.br/embrapa/?p=6409.

Accessed: Dec 14, 2017.

Faria LMV, Gomes MB, Silva TR (2013) Resposta morfológica do rabanete à aplicação de diferentes doses de silício na linha de semeadura. Revista Eletrônica da Univar 2(10):121-128.
Klar AE, Putti FF, Gabriel Filho LRA, Silva Júnior JF, Cremasco CP (2015) The effects of different irrigation depths on radish crops. Irriga 1(1):150-159. DOI: http://dx.doi.org/10.15809/irriga.2015v1n1p150

Konica Minolta Sensing (2009) Chlorophyll meter SPAD502Plus. Tóquio, 6p. Instruction manual.

Lacerda VR, Gonçalves BG, Oliveira FG, Sousa YB, Castro IL (2017) Características morfológicas e produtivas do rabanete sob diferentes lâminas de irrigação. Revista Brasileira de Agricultura Irrigada 11(1):1127-1134. DOI: http://dx.doi.org/10.7127/RBAI.V11N100513

Lima EMC, Maller A, Hara AT, Rezende FC, Carvalho JA (2015) Efeito de diferentes níveis de água no solo na produção do rabanete cultivado em dois tipos de ambientes protegidos. Engenharia na Agricultura 23(4):346-354. DOI: http://dx.doi.org/10.13083/14143984/reveng.v23n4p346-354

Noman A, Ali Q, Maqsood J, Iqbal N, Javed MT, Rasool N, Naseem J (2018) Deciphering physio-biochemical, yield, and nutritional quality attributes of water-stressed radish (Raphanus sativus L.) plants grown from Zn-Lys primed seeds. Chemosphere 195(3):175-189. DOI: http://dx.doi.org/10.1016/j.chemosphere.2017.12.059

Piekielek WP, Fox RH (1992) Use of a chlorophyll meter to predict sidedress nitrogen requirements for maize. Agronomy Journal 84(1):59-65. DOI:

http://dx.doi.org/10.2134/agronj1992.00021962008400010 $013 \mathrm{x}$

Silva AFA, Souza EGF, Barros Júnior AP, Bezerra Neto F, Silveira LM (2017) Desempenho agronômico do rabanete adubado com Calotropis procera (Ait.) R. Br. em duas épocas de cultivo. Revista Ciência Agronômica 48(2):328336. DOI: http://dx.doi.org/10.5935/1806-6690.20170038

Silva CL, Costa THM (2013) Barreiras e facilitadores do consumo de frutas e hortaliças em adultos de Brasília. Scientia Medica 23(2):68-74.

Silva RT, Souza AAT, Oliveira FA, Targino ISO, Silva MLN (2012) Tolerância do rabanete ao encharcamento do solo. Revista Verde de Agroecologia e Desenvolvimento Sustentável 7(1):25-33.

Slomp JJ, Leite JAO, Trentin A, Ledesma GS, Cecchin D (2011) Efeito de diferentes níveis de irrigação baseados em frações do tanque classe "A" sobre a produção de rabanete (Raphanus sativus L.) variedade "Crimson Giant". Revista Perspectiva 35(131):99-107.

Smeal D, Zhang H (1994) Chlorophyll meter evaluation for nitrogen management in corn. Communications in Soil Science and Plant Analysis 25(9):1495-1503. DOI: http://dx.doi.org/10.1080/00103629409369130

Sousa DN, Ferreira Neto JA, Cardoso PO, Milagres CSF (2011) A dinamização dos assentamentos rurais para o desenvolvimento econômico do Noroeste de Minas Gerais. Revista de Ciências Humanas 11(1):87-97.

Vidigal SM, Pedrosa MW (2007) Rabanete. In: Paula Júnior TJ, Venzon M (eds). 101 Culturas: manual de tecnologias agrícolas. Belo Horizonte, EPAMIG, p 661-664. 